\title{
THE COMPARATIVE ANALYSIS OF HIGHER SCHOOL STUDENTS' CONFLICTOLOGICAL CULTURE ON THE BASIS OF THEIR LEFT-/RIGHT- HANDEDNESS
}

\author{
Olga Shcherbakova \\ Plekhanov University of Economics, Moscow, Russia \\ Anna Tatarinceva \\ Baltic International Academy, Riga, Latvia
}

\begin{abstract}
We face with different kinds of conflicts every day. The problem of the conflictological culture of personality is urgent nowadays, because only a person with a highly developed level of the ability to avoid or successfully solve conflicts can succeed at work and in life-long learning. The European Council defined five key competences necessary for future specialists' successful functioning in the contemporary society. The first place in this list was assigned for social competence as the ability to be responsible, able to take part in group decisions, avoid and resolve conflicts (The Symposium of the European Council. Brussels, 1996). The authors of the given research analyze the essence of the notions "conflict", "conflictological culture", as an integral quality of a person where the main stress is paid on its structural components' content. They also investigate different aspects of activities and psychophysiological development of left- and right-handedness of people. The empirical analysis conducted in the research presents the data obtained in the investigation of the left- and right-handed students' conflictological culture's level. The Object of the research is the conflictological culture's level of students at higher school. The Aim of the research is to investigate: 1) the essence of the notions " conflict", "conflictological culture", 2) the level of conflictological culture of students of the $1^{\text {st }}$ and $4^{\text {th }}$ courses at higher school on the basis of their left-/right-handedness. The Methods of the research are the following: 1. Theoretical methods: The theoretical analysis of scientific literature on the given problem. 2. Quantitative methods: questionnaires. 3. The empirical analysis of obtained data
\end{abstract}

Keywords: avoidance,behavior,cognition,conflict, conflictological culture, development, hemisphere, higher school, interaction, left-/right-handedness, personality, relationship, students.

\section{Introduction}

Conflictness is an integral property of a personality reflected the frequency of her/his entry in interpersonal conflicts. The measure of conflictness is the microclimate characterized by the group members' emotional satisfaction expressed in mutual collaboration, styles of group relationships, psychological atmosphere, group spiritual values (Rober, 2008). According to the authors' opinion, one of the most important characteristics of an individual nowadays is his/her conflictological culture helped young people to interact with the surroundings and the inner world successfully. A person should have the appropriate level of conflictological culture in order to be able to resolve conflict 
situations constructively. The problem of forming the young generation's conflictological culture is urgent nowadays. Contemporary society is characterized by the increasing level of competition and continuous rapid changes in many spheres of modern life caused the emergence of conflicts. One can find a lot of definitions determined the essence of the notion 'conflict' in scientific literature. A conflict is: 1. A fight, struggle; a controversy or quarrel, strife or incompatibility (Finnegan, 2010); 2. A bitter disagreement among employers and workers, opposition (Hornby, 2008); 3. A clash of opposing goals, needs, interests, desires, norms, values, positions of subjects of interaction under the necessity to reach an agreement (Petrovsky, 2005); 4. A clash occurred among the subjects of interactions for meeting needs, purposes, resources (usually limited) important for them (Shcherbakova, 2013). A conflict is developed when one side starts to infringe the interests of another one (Petrovsky, 2005). The recognition of a conflict as an inevitable daily and frequent phenomena actualizes the need to develop specific rules of conduct and implementing effective solutions to emerging issues. Conflictological culture of personality can be defined as his/her ability to predict, prevent and resolve conflicts (Rober, 2008). It is important to teach contemporary students at higher school, future specialists, how to avoid conflicts or resolve them effectively. Conflictological culture of a specialist is the ability for acquisition and implementing professionally oriented conflictological knowledge necessary for the perception of the professional conflict-prone environment and the subsequent implementation of professional duties in a professional conflict (Samsonova, 2007). Conflictological culture is the integrating function of other components of professional culture, they are-communicative culture, information culture, methodological culture, psychological culture (Samsonova, 2007). Components of professional culture are very important for the determination of a specialist's conflictological culture-they are: 1.professional knowledge-literacy, special language...; 2.professional psychological readinesscognition, intuition, forecast, reflection...; 3.professional competence-skills, methods of implementing activities... So, one can highlight the following components in the structure of a specialist's conflictological culture based on above-mentioned: 1. conflictological competence (professional knowledge about conflicts and their manifestations, the system of conflictological skills and attitudes in conflict management); 2.conflictological readiness (professional readiness for conflict management, the successful conflict resolution, the choice of optimal behavioural strategy). The authors of the given research believe, that the optimal choice of a behavioural strategy by a specialist in a conflict situation and emotional Self-management are the indices of the conflictological readiness's formation. The presence of conflictological culture suggests the formation of not only specific knowledge and practical skills, but also the existence of a range of certain abilities, attitudes formed the basis for better understanding of others and Self, Self- improvement and Self- development 
thanks to the constructive mutual interaction in the problems' resolution. Conflictological culture of a personality represents the integrative quality based on existing spiritual values included the culture of cognition, feelings, communication and behaviour manifested in optimal interaction strategies ensured the constructive conflict resolution (Shcherbakova, 2013). (Grishina, 2008) believes that the valuable semantic kernel of conflictological culture is a conflict position of a personality which is analyzed as a stable hierarchical system of attitudes to a conflict, its structural and dynamic components determined a dominated selective attitude to own participation in a conflict and the achievement of a conflict' desired resolution. A formed conflict position determined a stable attitude to a conflict, subjects of a conflict, ways and methods of a goal's achievement, defines the optimal strategy's choice and increases the level of conflictological culture. The authors of the given research conclude that conflictological culture takes a dominated position in a structure of personal general culture as it promotes a person's humane development that helps students in successful communication, collaboration and support during their learning at higher school and further in life-long learning.

\section{Left-Handedness Versus Right-Handedness}

Scientists (Dunn et al., 1998), (Milgram, 1992), (Griggs, 1994), (Restak, 1999) believe that about $85 \%$ of the world population are right-handed people, the rest of them are left-handed people, there are about 500 million left-handed people on the Earth. Only some percent of people can implement both hands equally well, such people are called ambidexters. These people have the inborn or acquired equal development of both hands' functions and the ability to implement moving actions by the left and right hands with the same speed and efficiency. The ambidexters have the even developed hemispheres of their brain. Such people quickly assess a situation and make decisions (Tolkien \& Eldarin, 2005). The differences of human brain's functioning called functional asymmetry offer the insight to the human brain's structure. (Luria, 1973) in his "The Concept of Lateralization" firmly believes that if a person is right-handed, his/her left cerebral hemisphere is lateralized for handedness and the control of his/her speech so he/she is left-lateralized. Each hemisphere controls the opposite part of a human's body. Let's analyze each hemispheres implementing human brain's functions. (Zdenek, 1983), (Price, 1997), (McCarthy, 1990), (Milgram, 1992) believe that higher school students with the left (The Left Mode) or the right (The Right Mode) hemisphere dominated have such characteristics: 
Table 1. The preferences of students with right-/left-dominated hemispheres

\begin{tabular}{|c|c|}
\hline $\begin{array}{l}\text { Students With The Left Hemisphere } \\
\text { Dominated: }\end{array}$ & $\begin{array}{l}\text { Students With The Right Mode } \\
\text { Dominated: }\end{array}$ \\
\hline $\begin{array}{l}\text { are rational, auditory, relective, field- } \\
\text { independent objective, planned, structured, } \\
\text { theoretical, respond well to verbal } \\
\text { instructions, they have analytical thinking, } \\
\text { solve problems by logical and sequential } \\
\text { ways by looking at details, think } \\
\text { successively, step-by-step, prefer objective } \\
\text { tests, speaking, writing and working with } \\
\text { digits, letters and formal laws, hierarchical } \\
\text { authorities, controlled systematic } \\
\text { experiments, look at differences, are } \\
\text { responsive to structure and established } \\
\text { certain information, analyze, rely on words, } \\
\text { language in thinking and remembering, } \\
\text { comprehend causes and effects, control } \\
\text { feelings, tend to feel more positive } \\
\text { emotions, the majority of them have } \\
\text { mathematical abilities. }\end{array}$ & $\begin{array}{l}\text { are intuitive, visual, subjective, changeable } \\
\text { and spontaneous, impulsive, rapid, free with } \\
\text { feelings, emotional, mainly mute, } \\
\text { experimental, imaginative, more sensitive to } \\
\text { natural sounds, responsive to ambience, } \\
\text { respond well to demonstrated instructions, } \\
\text { prefer open-ended tasks, usually offer } \\
\text { several decisions of a problem, solve } \\
\text { problems by relying on intuition, looking } \\
\text { for patterns, configurations and similarities, } \\
\text { prefer essay tests, schematic figures, } \\
\text { manipulating, collegual authority, elusive } \\
\text { uncertain information, tactile } \\
\text { discriminations, global identity matching, } \\
\text { visual and spatial activities, paradigm- } \\
\text { shared theories, drawing, taking } \\
\text { photographs, they synthesize, rely primarily } \\
\text { on images in thinking and remembering, } \\
\text { tend to feel more negative emotions, use } \\
\text { pictures, not words, comprehend the whole } \\
\text { idea, correspondences, excel in poetic, } \\
\text { metaphoric language, prone to abrupt mood } \\
\text { swings }\end{array}$ \\
\hline
\end{tabular}

Raymond et al., (2006) believe, that left-handed male-students are met more frequently than female-students. As for these scientists, one from five outstanding personalities is a left-handed person. Cognition and behaviour of the left-handed differ from the right- handed people, that could be explained that connections between two brain hemispheres of the left-handed are not so stringent as in the right-handed brain, that is why information in the cerebral cortex is processes more slowly. Mental illness in the left-handed mostly progresses differently than in the right-handed, many of the left-handed possess extrasensory abilities (Lombroso, 1876). The left-handed children adapt to school more difficult than their right-handed peers. Rather many left-handed schoolchildren have difficulties with remembering directions 'right-left', 'updown' (Rober, 2008). Why some people were born the left-handed but others the right- handed ones is uncertain.

\section{The Comparative Analysis of Student Conflictological Culture's Level on The Basis of Their Left-/Right-Handedness}

The authors of the given paper conducted the research in order to determine the relationship between students' conflictness and their belonging to 
the left-right-handedness in November 2014. 140 respondents took part in the research, they were 68 male- students and 72 female- students.

Table 2. Data of a sample of respondents

\begin{tabular}{|l|l|l|l|l|}
\hline $\begin{array}{l}\text { Volume of a } \\
\text { general sample }\end{array}$ & $\begin{array}{l}\text { Volume of an } \\
\text { aggregate } \\
\text { sample }\end{array}$ & $\begin{array}{l}\text { Type of a } \\
\text { sample }\end{array}$ & $\begin{array}{l}\text { Unit of } \\
\text { measurement }\end{array}$ & $\begin{array}{l}\text { The geography } \\
\text { of the research }\end{array}$ \\
\hline 5000 people & $\begin{array}{l}68 \text { male- } \\
\text { students } \\
\text { (at the age of } \\
19-24)\end{array}$ & Spontaneous & $\begin{array}{l}\text { Young women } \\
\text { and men }\end{array}$ & $\begin{array}{l}\text { Moscow } \\
\text { (Russia) and } \\
\text { Riga (Latvia) }\end{array}$ \\
\hline & $\begin{array}{l}72 \text { female- } \\
\text { students } \\
\text { (at the age of } \\
19-24)\end{array}$ & & $\begin{array}{l}\text { Plekhanov } \\
\text { Russian } \\
\text { University of } \\
\text { Economics and } \\
\text { The Baltic } \\
\text { International } \\
\text { Academy }\end{array}$ \\
\hline
\end{tabular}

The volume of a general volume characterizes the approximate number of respondents in both higher schools. The volume of an aggregate sample characterizes the number of respondents required for calculating results in percentage. A spontaneous sample allows to make the objective precise analysis. Units of measurement are young women and men as we study the opinions of students. The research was conducted at two higher schools in Russia and Latvia. The Aim of the empirical part of the research is the analysis of conflictness of left-/and right-handed students of the $1^{\text {st }}$ and the $4^{\text {th }}$ course at Plekhanov Russian University of Economics and The Baltic International Academy. The authors of the research had to evaluate a Self-assessment level of students' conflictness. In order to implement that, the authors used the method " Self-Assessment of a Conflict Level" by (Emelyanov, 2009). During the use of the above-mentioned technique the arithmetic mean of a Self-assessment level of students' conflictness was calculated and the obtained results are shown on the Figure 1.

The Figure 1 represents the comparison of arithmetic means of a Selfassessment level of students' conflictness of female- and male- students of the $1^{\text {st }}$ and $4^{\text {th }}$ courses studied at two above-mentioned higher schools. One can see that arithmetic means of a Self-assessment level of female-students of the 1 course are located on the level which is "a bit below the medium level" of conflictness, but it is increased till the medium level of conflictness when female-students became the students of the $4^{\text {th }}$ course. The increased level of female-students' conflictness at the 4 course could be explained by their fatigue caused by the hard preparation for future state examinations and writing a thesis. The authors can also add that many female-students were married, some of them 
had children, some female- students expected a baby during the given investigation, also many of these young women worked after their learning at higher school.

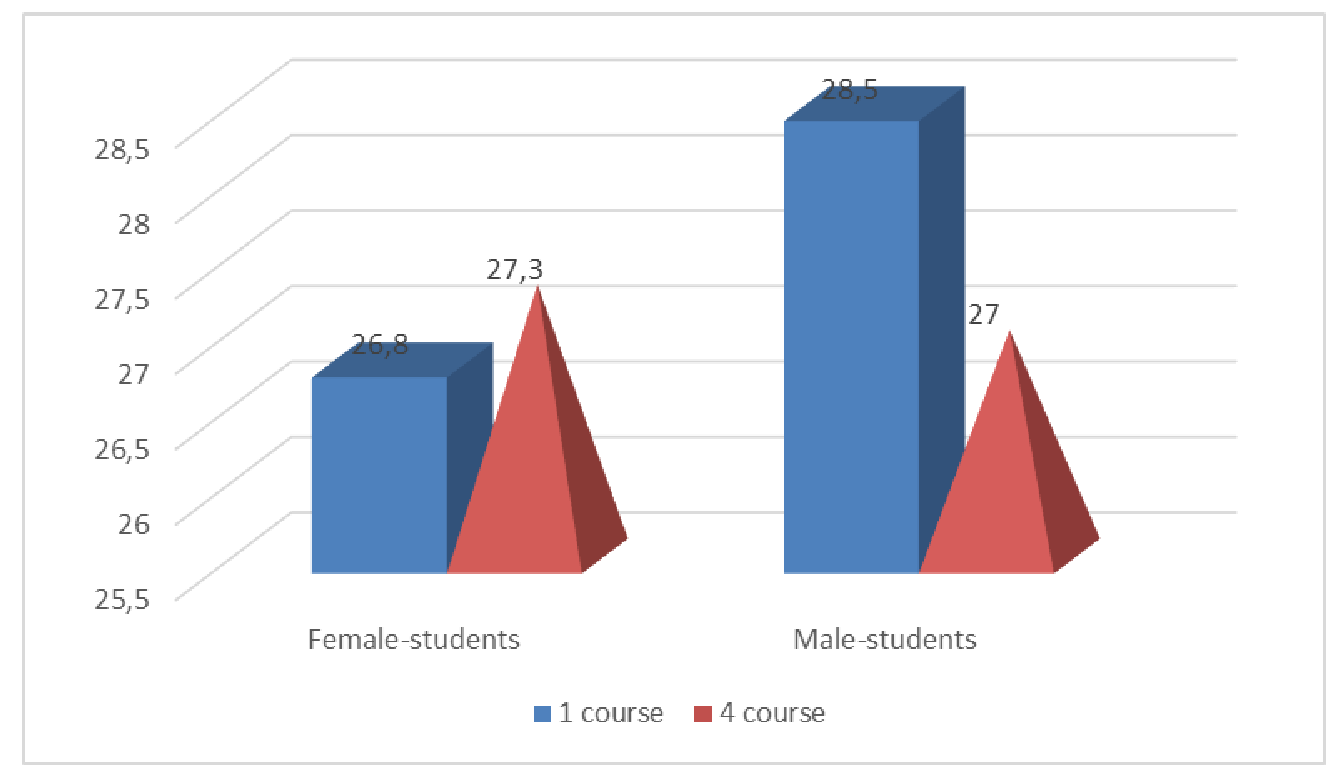

Figure 1. The comparison of the arithmetic means of a Self-assessment level of students' conflictness of female- and male- students. The index 27 represents the medium level of conflictness

As for male-students, the level of their conflictness is located on the medium index for students of the $1^{\text {st }}$ course but in general the level of malestudents' conflictness is rather higher than their female- peers. Male-students of the $4^{\text {th }}$ course became rather less conflicted than male-students of the $1^{\text {st }}$ course. It can be explained by the higher degree of tolerance, empathy and patience of undergraduates that were formed during their long learning together.

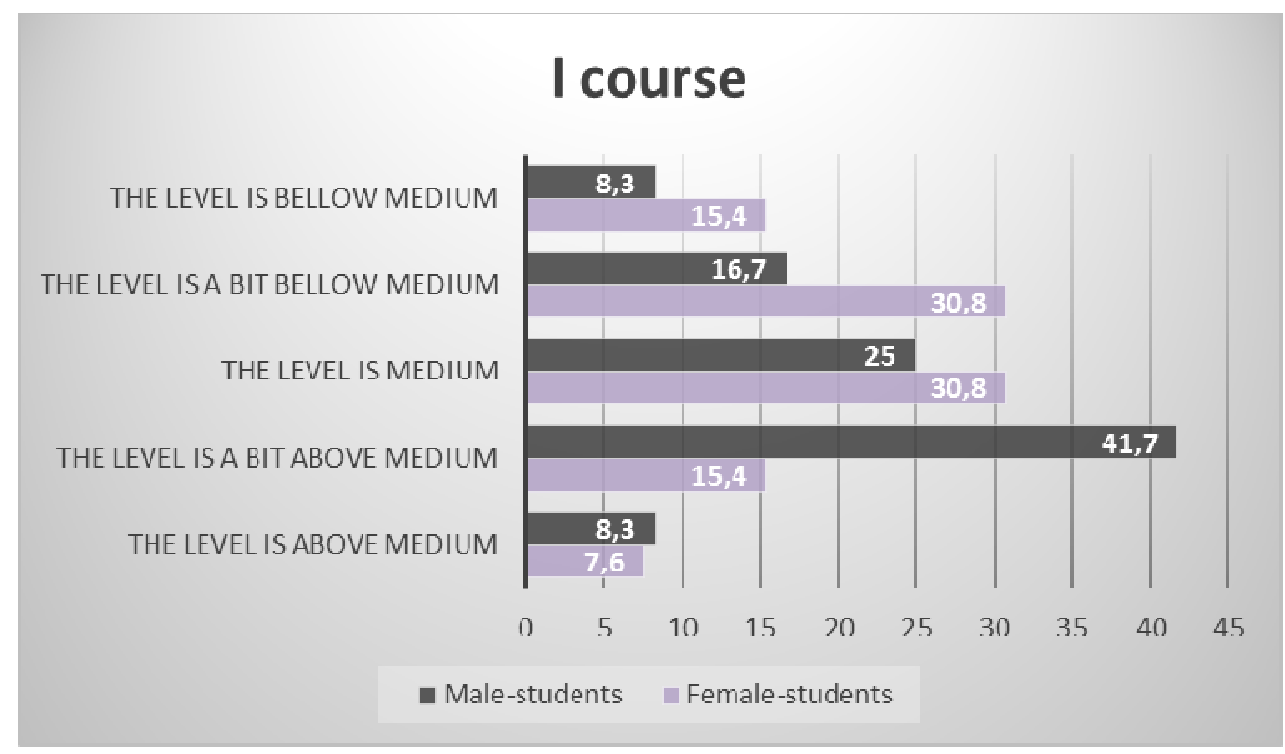

Figure 2. The Indices of the 1 course's students conflictness's level 
One can see from the Figure 2 that the majority of young men studied on the $1^{\text {st }}$ course have the level of conflictness which is ,a bit above the medium level" and is equal to $41.7 \%$, "the medium" level of conflictness takes the second place and is equal to $25 \%$, the index of the conflictness's level which is "a bit below the medium level" is equal to 16.7, and indices of "above the medium level" and "below the medium level" are equal to $8.3 \%$. Femalestudents of the 1 course have the highest percent of conflictness which can be shared between "the medium level" and "the level a bit below the medium" and this percent is equal to $30.8 \%$, the second place can be shared between " the level which is below the medium level" and "the level which is a bit above the medium level", they are equal to $15.4 \%$, and the level of conflictness which is "above the medium level" is equal to $7.6 \%$.

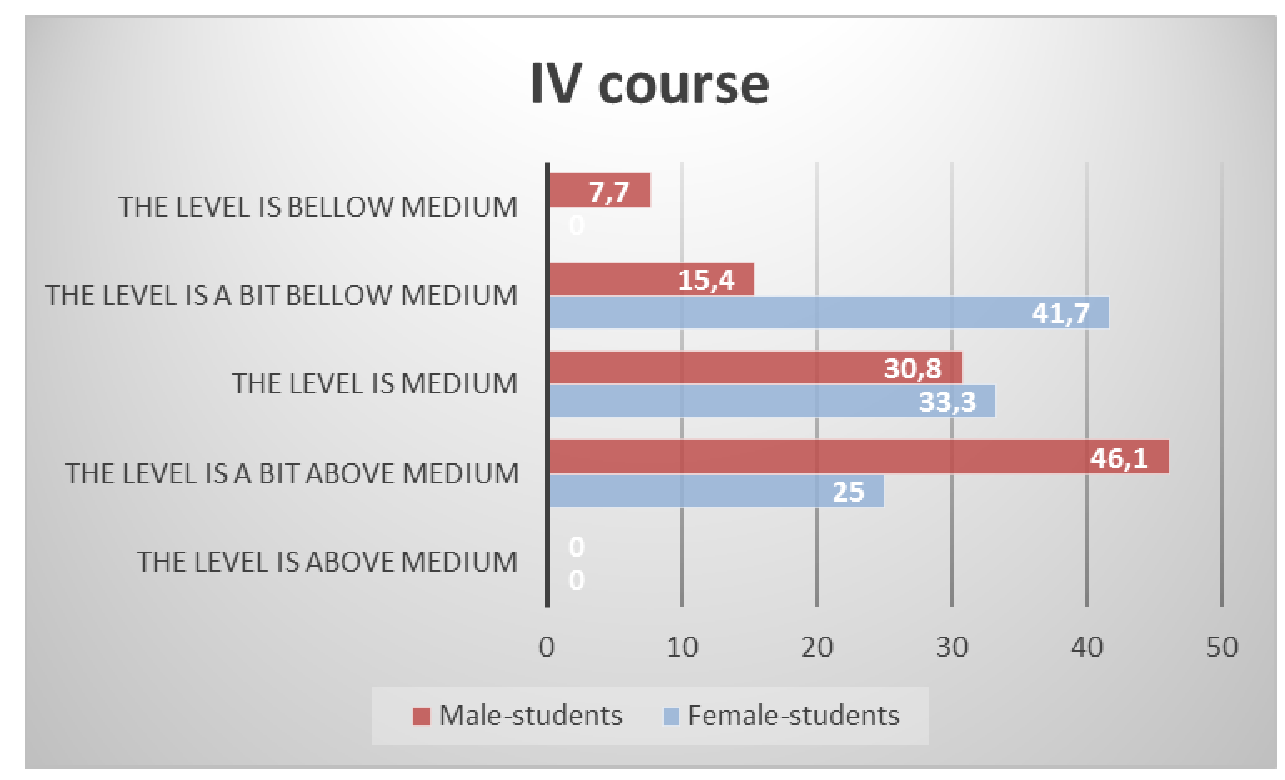

Figure 3. The Indices of the $4^{\text {th }}$ course students' conflictness's level

As one can see from the Figure 3., the majority of male-students of the $4^{\text {th }}$ course have the level of conflictedness that is "a bit above the medium level' and is equal to $46.1 \%$, "the medium level' of conflictness takes the second place and is equal to $30.8 \%$, the level of conflictness that is "a bit above the medium level" is equal to $15.4 \%$, the level of conflictness which is "below the medium level" is equal to $7.7 \%$, and the level of conflictness which is "above the medium level' is equal to $0 \%$. Female-students of the $4^{\text {th }}$ course have the highest percent of conflictness that is ,a bit below the medium level" and is equal to $41.7 \%$. The second place takes "the medium level" of conflictness which is equal to $33.3 \%$, the third place belongs to the level which is ,a bit above the medium level" of conflictness and is equal to $25 \%$, levels of conflictness which are "above the medium level" and "below the medium level" are equal to $0 \%$. The right-handed students have higher indices on the scale „Estrangement in relations" that characterizes the desire to move away from others and shows the 
excessive concentration on Self, preoccupation and the increased concern about relations which are unstable, restless and uncomfortable according to students' perception. The factual tension in relations with others takes place in the behaviour of the right- and the left-handed- students. The left-handed students $(68 \%)$ are more conflicted in comparison to their right-handed peers. Any clearly expressed asymmetry causes tension, as anyone has the only channel of interaction- that is a rational channel, or the emotional one (Luria, 1973).

\section{Conclusion}

The data obtained from the result of the research show that:

1. The level of conflictness of students of the $1^{\text {st }}$ and the $4^{\text {th }}$ courses are in the range of mean values. Female-students have the level of conflictnessequal to $27.5 \%$, male- students have the level of conflictness equal to $27.8 \%$. The trend to the slight increase of the conflictness's level was revealed of female-students (from $26.8 \%$ till $27.3 \%$ ), the conflictness's level of male-students, in opposite, decreased (from $28.5 \%$ till $27.0 \%$ ) during their learning at higher school;

2. The students of the $1^{\text {st }}$ course are more conflicted in comparison to the students of the $4^{\text {th }}$ course (with different results by gender);

3. The left-handed students $(68 \%)$ are more conflicted in comparison to the right-handed students;

4. As the result of the given research the authors conclude that the main reason of students' increased conflictness is their inadequate level of conflictological culture's formation.

\section{References}

Dunn, R., Dunn, K. \& Price, G. (1998). Hemispheric Preference. NJ: Phi Delta Kappan.

Finnegan, E, (2010). New Webster's Dictionary of The English Language. Delhi: Surjeet Publications.

Griggs, S. (1994). Counseling Students Through Their Learning Styles. NJ: Eric.

Grishina, N. (2008). Psychology of Conflict. Saint-Petersburg: Piter.

Hornby, A.S. (2008). Oxford Student's Dictionary of Current English. Oxford: Oxford University Press.

Lombrosso, C. (1876). The Criminal. NY: Putnam.

Luria, A. (1973). The Working Brain. NY: Basic Books.

McCarthy. (1990). Using The 4MAT Model. Educational Leadership, 48, 31-37.

Milgram, R. (1992). Teaching Gifted And Talented Adolescents. Connecticut: Praeger.

Price, G. (1997). Human Brain: An Exploration. London: Penguin Books.

Raymond, M.; Pontier, D; Dufour, A \& Pape, M. (2006). Frequency-Dependent Maintenance of Left-Handedness in Humans. Proceedings of Royal Society of London, B. 263, $1627-$ 1633.

Restak, R. (1999). The Brain : The Last Frontier. NY: Doubleday.

Rober, M. (2008). Psychology of Individual and Group. Moscow: Academia.

Shcherbakova, O. (2013). Psychology. Moscow: Rue. 
Tolkien, J.R. \& Eldarin, R.R. (2005). Hands, Fingers, Numerals and Related Writings-Left and Right. Grofton, MD: C.F. Hosteter.

Zdenek, M. (1983). The Right Brain Experience. London: A Corgy Book.

Емельянов С.М. (2009). Практикум по Конфликтологии. Санкт- Петербург: Питер.

Петровский, А.В. (2005). Основы Теоретической Психологии. Москва: Инфра.

Самсонова, Н. (2007). Формирование Конфликтологической Культуры Специилиста. Российский Государственный Уиверситет имени Канта. Калининград: Наука. 